\title{
Financial stability and local economic development: the experience of Italian labour market areas
}

\author{
Cristian Barra ${ }^{1,2} \cdot$ Roberto Zotti $^{3}$ D
}

Received: 8 December 2020 / Accepted: 12 May 2021 / Published online: 26 May 2021

(c) The Author(s) 2021

\begin{abstract}
Regulators should ensure the smooth functioning of the system and promote regional development. Making the health of financial institutions is therefore a prerequisite for a sustainable economic development. This paper contributes to the literature on the relationship between the financial stability and growth within the area of one country. This implies that institutional, legal, and cultural factors are more adequately controlled for and financial markets are more accurately bounded. Using a rich sample of Italian banks over the 2001-2012 period, this paper addresses whether different measures of financial distress affect economic development of labour market areas in Italy. Results show that the financial stability has a positive effect on local economic development, robust to alternative variables capturing financial vulnerability. The presence of spatial effects is tested showing that better financial conditions of the banking system in neighbouring areas have a detrimental effect on an area's growth.
\end{abstract}

Keywords Banks $\cdot$ Local economic development $\cdot$ Financial stability $\cdot$ Labour market areas

JEL Codes $\mathrm{G} 21 \cdot \mathrm{G} 28 \cdot \mathrm{R} 11 \cdot \mathrm{C} 20$

Cristian Barra

cbarra@unisa.it

Roberto Zotti

roberto.zotti@unito.it

1 Department of Economics and Statistics, University of Salerno, Via Giovanni Paolo II, 132, 84084 Fisciano, SA, Italy

2 Centre for Labour Economics and Economic Policy (CELPE), Via Giovanni Paolo II, 132, 84084 Fisciano, SA, Italy

3 Department of Economics and Statistics "Cognetti De Martiis", University of Torino, Campus Luigi Einaudi, Lungo Dora Siena 100A, 10153 Torino, Italy 


\section{Introduction}

Financial stability represents a condition in which the financial system can withstand shocks without major disruption in financial intermediation and in the effective allocation of savings to productive investments (ECB 2012). In other words, the financial system is stable when it succeeds in transferring resources from savers to investors, in assimilating financial and real economic shocks, and in managing financial risks. Financial stability is a prerequisite for sustainable economic performances (see Dudley 2011). The recent financial crisis prompted policymakers and regulators to analyse whether the level of bank distress can influence economic development. Indeed, the core of the financial system-major banks, non-bank financial intermediaries, and financial market infrastructuresshould be made more resilient to adverse shocks and less susceptible to runs. This is true even though the openness of markets, the increased mobility of capitals, the growth of integration between countries, and the complexity of the financial instruments make the financial markets more vulnerable to several risks.

Among the main sources that make the financial system unstable, there is the risk-taking of banks. When financial institutions take more risks and allocate capital less efficiently, then the banking system is more vulnerable to economic shocks, producing negative effects for the economy as a whole. Other risks faced by the financial institutions, such as that of credit, may depend on the discretion of managers who may take unnecessary risks in the interest of the bank. The existence of risky assets entails additional monitoring and screening costs that banks must sustain in order to quantify them. It follows that concentrated markets can count on higher capital, part of which is invested in monitoring and screening processes to reduce the share of risk-taking (Berger and DeYoung 1997). In the European context, regulators have tried to make banks more reliable (i.e. Basel II reform) to allow more lasting relationships for both firms and households. Indeed, financial stability induces a better and a smoother allocation of resources, mobilizes savings, reduces risks, facilitates transactions, and ensures the emergence of innovative firms. In turn, economic performance can improve by converting the liquidity from deposits and savings to long-term investments. On the other hands, this mechanism might also create damage if deregulation and the presence of information asymmetries encourage banks to take more risks.

The main contribution of this paper is investigating both the direct and indirect effects of bank soundness and financial stability on local economic development. More specifically, the paper is closely related to the less-debated strand of the literature that considers the role of financial markets at the local level within countries (Usai and Vannini 2005; Valverde et al. 2007; Hasan et al. 2009; Destefanis et al. 2014; Coccorese and Silipo 2015; Cavalcante 2018). It is very difficult to underline the role played by financial stability across countries with different backgrounds. We believe that investigating whether and how a high degree of bank soundness affects economic growth using data at the sub-national, rather than the national level, is particularly relevant. It is, instead, more appropriate to focus on local territories within a single country where history, institutions, and 
legal framework are more homogenous. If the presence of a stable and efficient financial system can have a specific economic-stimulus impact, it is much more likely that this is more evident at the local level. In this framework, the money is tied to practical actions and interventions near where it is used for growthenhancing purposes, such that the interaction between financial intermediaries, households, and firms is more accurately defined and resources can be mobilized more efficiently. To capture this perspective, we rely upon highly territorially disaggregated data such as Italian labour market areas (LMAs) corresponding to a deeper territorial disaggregation than NUTS 3-level subdivisions (see Sect. 2.2 for details on LMAs). To capture the financial vulnerability of banks and to predict their distress, bank soundness is firstly calculated through the Z-score (the number of standard deviations by which returns would have to fall from the mean to wipe out all equity in the bank). We then make use of the accounting-based CAMELS variables (which stand for capital, asset quality, management, earnings, liquidity, and sensitivity to market risk). A two-step system GMM estimator with Windmeijer (2005)-corrected standard error in dynamic panel specification, over the period 2001-2012, is used to deal with the suspected endogeneity between the stability of the financial system and economic performance.

Results show that financial stability positively affects local economic development (Destefanis et al. 2014; Coccorese and Silipo 2015), and these results are robust to the use of more widely used indicators of financial stability, such as return on equity and return on assets, and to alternative variables capturing financial vulnerability (Chiaromonte et al. 2015). Stable banks, located in the territories that grow more, act as a stimulus to reach higher levels of operations. The financial stability of banks still has a positive and significant effect on local economic development, but lower in magnitude, in the years after a crisis. Finally, while the introduction of spatial effects does not modify the main conclusions, results also provide evidence that the presence of more efficient banking services in the geographic vicinity generates a pull effect due to the possibility that borrowers and investors may be attracted to these nearby services, take out credit, and consume in neighbouring areas (Hasan et al. 2009).

The rest of the paper is organized as follows. Section 2 overviews the literature on the relationship between financial stability and economic development and the relative channels, highlighting the importance of a local perspective in the analysis. Section 3 describes the empirical approach, the measures of financial stability, and the data used in the analysis. Section 4 shows the main findings, underlining the accuracy of different sources of financial stability affecting economic development. Section 5 provides some robustness checks. Finally, Sect. 6 concludes. 


\section{Financial stability and economic development: a regional perspective}

\subsection{Financial soundness-growth nexus: theoretical and empirical background}

The literature highlights a positive relationship between financial development and economic growth (Bumann et al. 2013), drawing on cross-country (King and Levine 1993), time series (Arestis et al. 2001), and panel studies (Beck and Levine 2004). Due to a better allocation of resources, risks, and transactions, the stability of the financial sector can be an engine of growth. Several measures of financial development, defined as the policies, factors and institutions that lead to efficient intermediation and effective financial markets (WEF 2012), are used. The size of financial intermediaries is considered through the proportion of liquid liabilities (King and Levine 1993; Huang 2005) and the ratio of bank deposit liabilities to gross domestic product (Demetriades and Hussein 1996). The importance of the banking sector is also taken into consideration by using the ratio of credit issued to the private sector to liquid liability (Saci and Holdied 2008). Proxies for banking sector development include bank deposits over gross domestic product, banks' overhead costs, banks' concentration, and banks' net interest margins (Antzoulatos and Thanopoulos 2008). The concept of liquidity preference is also used to analyse the effect of money behaviour on the regional economic performance of regions (Crocco et al. 2005).

Despite the above-mentioned measures of performance and activities of financial institutions, the importance of making the financial system stable has to be defined. How should changes in banking sector soundness affect economic development? The higher the financial stability of the system, the larger the level of capital held by the banks, and the greater their profitability. This ensures a substantial distribution of loans to households and firms. In turn, the higher the borrowing levels, the more sizable are the investment projects, with positive consequences on growth levels. Therefore, one important channel is that of credit. Since Schumpeter, research and development activities, and likewise patents, are considered as new ideas and pieces of knowledge that may turn into innovation when commercially exploited (Schumpeter 1934, 1942). Entrepreneurs need credit to finance their innovations, and banks as well as financial markets could facilitate this mechanism. Bank-based systems (differently from marked-based systems) create more stable relationships and convince entrepreneurs to invest in innovation (Stiglitz 1985).

In this prospect, financial development refers to the increased functionality of local financial institutions in intermediating services related to investment and growth (Cavalcante 2018). More specifically, the relationship between finance and growth depends also on the firm's reliance on external funds (Guiso et al. 2005; De Serres et al. 2006). Regional concentration and centralization of the banking system are relevant for firms' investment choices (Cavalcante 2018). The ability of firms to better capture growth opportunities, thanks to the funding for investment, is relevant (Fisman and Love, 2004), as is firms' probability of entry and survival in the market (Aghion et al. 2007; Beck et al. 2008). An improvement in 
the borrowing conditions, due to more favourable credit standards, may help to produce a friendly environment for savers and investors. Consequently, resources are allocated more efficiently (Lown et al. 2000). A positive effect on economic development is expected in case financial institutions keep their minimum credit standards balanced, making it easier for borrowers to receive funding.

An additional channel through which financial stability can lead to increasing economic development is a decrease in cost for firms and households of financing spending. A more stable banking system may help to reduce interest rates on business and consumer debt, leading firms, and households to favour spending. In contrast, uncertainty due to financial instability of the banking system may make firms more careful about their investment and may prompt households to decrease their spending, since uncertainty affects the expected value of their future wealth, negatively affecting economic development (Hakkio and Keeton 2009; Bauducco et al. 2011; Carlson et al. 2011). Financial intermediaries can promote economic development also by monitoring the investment projects, as borrowers need to be scrutinized to prevent moral hazard ex-post. There is evidence that in more concentrated markets management efficiency generates a decrease in risk-taking behaviour with respect to partially competitive markets. This is consistent with the idea that banks with less local competition are able to increase their profits by indulging more freely in rent-seeking behaviour, minimizing their risk-taking. Therefore, the quality of their assets improves through additional screening processes (Barra et al. 2016a).

\subsection{The relevance of an intra-regional approach in financial market research: the case of Italy}

It is specifically at the regional or even sub-regional level that factors related to the location of economic actors may affect the relationship between financial stability and economic development. Financial intermediaries strategically open branches at the local level to offer services where they could better serve households and small business (Dow and Rodriguez-Fuentes 1997; Williams and Gardner 2003). Through this channel, they contribute more successfully to increase the social level of territories (Fuller and Jonas 2002). Borrowers might also prefer local solutions to build their borrowing relationship (Zazzaro 1997) as local banks are better informed on local economic conditions. Moreover, at the lower territorial level, monetary, legal, and cultural environments, where not observed, could more safely be assumed to be homogenous. Valverde and Fernandez (2004) analyse financial deepening and banks' dependence, taking into account banks' lending specialization. They strongly suggest that this relationship is likely to be more adequately evaluated at the regional level. Usai and Vannini (2005), within the context of Italy's regional economic growth, show that the financial sector has a weak impact on growth, while, instead, cooperative banks and special credit institutions play an important role. Valverde et al. (2007) show that service-producing institutions that deliver innovations contribute positively to regional gross domestic product. Hasan et al. (2009) show evidence of banks' abilities to provide financial services and products efficiently, from cost and profit perspectives, that positively affect regional growth. Coccorese and 

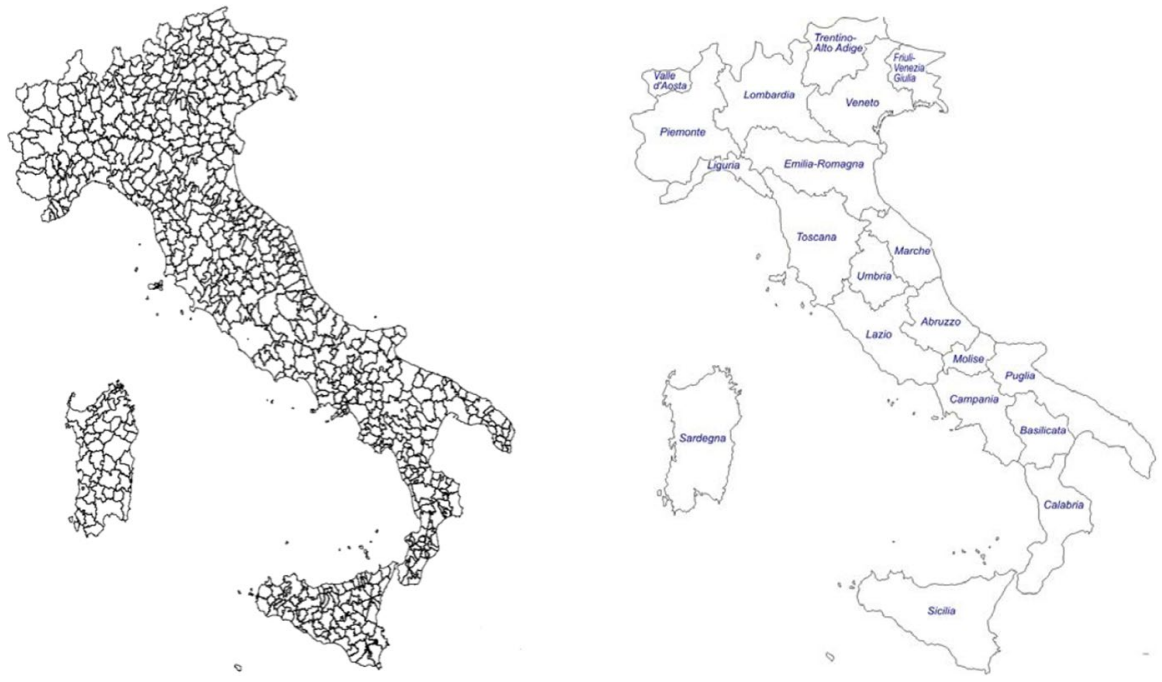

Fig. 1 Territorial location of LMAs and regions in Italy - Year 2011. Notes: our elaboration

Silipo (2015) find that finance is more relevant for growth in less developed areas of the country, even though the expansion of the financial sector has not helped to overcome the economic disparities between the two parts of Italy. The nexus between financial development and economic growth, relying upon territorially disaggregated data, has also been underlined by Destefanis et al. (2014). They use both qualitative and quantitative proxies of financial development and find a positive and significant impact on gross domestic product per worker. This paper constitutes a natural key reference, as our study moves from it and uses both market-based and accounting-based measures of bank distress (higher or lower probability of insolvency risk) to explore their ability to predict local economic development.

To take into account the importance of measuring the financial stability-economic development relationship at the sub-national level, we rely on LMAs. They correspond to sub-regional geographical areas where the bulk of the labour force lives and works. It is also where establishments can find the largest amount of labour force necessary to occupy the offered jobs (see also Destefanis et al. 2014; Faggian et al. 2018). More specifically, LMAs stand for a group of municipalities-akin to the UK's travel-towork-areas-adjacent to each other, geographically and statistically comparable, and characterized by common commuting flows of the working population. According to the Italian Statistical Office (ISTAT), they represent the place where the individuals live and work and, above all, where their economic and social relationships take place and are defined on a functional basis, the key criterion being the proportion of commuters who cross the LMA boundary on their way to work. Nearly half of the LMAs in Italy (314, equal to $47.7 \%$ of the total) stand in the size class from 10 to 50 thousand inhabitants, whereas the highest-density population (3957.2 per square kilometre) lives in the LMAs of Naples. Rome is the biggest LMA in Italy. Sicilia is the region with 
the highest number of LMAs in Italy (77), followed by Lombardia (58) and Campania (54). In contrast, Molise and Valle d'Aosta, showing nine and three LMAs, respectively, are those with the smallest number of areas. See Fig. 1 for a graphical representation of the LMAs' and regions' territorial location in Italy. Table 8 in the Appendix, instead, summarizes some LMAs' characteristics by regions and territorial location. To be more precise, the dataset covers almost half of the LMAs of the country, as we concentrate the analysis only on those areas where at least one bank branch is present (see Sect. 3 for more details on the construction of the dataset). More specifically, we include $46 \%$ of the LMAs of the north-west area of the country. Around $63 \%, 47 \%$, and $28 \%$ of the LMAs of the north-east, centre, and south of Italy, respectively, are taken into account (see Table 9 in the Appendix).

The Italian financial context fits perfectly with our research question, as important differences regarding the competitiveness of the markets and the efficiency of the financial intermediaries are present among different geographical areas. Consequently, the quality of the credit provided to firms and households may be consistently different according to the area where banks are located (see Table 10 in the Appendix for some descriptive statistics on credit market structural indicators for Italy). Interestingly, when it comes to a market concentration index-higher in the South than in the North - the data show the presence of a tight oligopoly in the former area and of a loose oligopoly in the latter.

\section{Empirical strategy and data}

\subsection{Investigating the stability-growth nexus: the advantage of a sub-regional approach}

To analyse the relationship between the stability of the financial system and local economic development, we specify the following dynamic panel model:

$$
\begin{gathered}
\ln G D P C_{i, t}=\alpha_{1} \ln G D P C_{i, t-1}+\beta_{1} \ln F S_{i, t}+\gamma_{1} L G_{i, t} \\
+\gamma_{2} \ln T P C_{i, t}+\gamma_{3} \ln B C_{i, t}+\gamma_{4} T I M E_{t}+\mu_{i}+\varepsilon_{i, t}
\end{gathered}
$$

where $\ln$ is the natural logarithm, and GDPC is gross domestic product per capita (measured as the sum of the gross values added of all units divided by workers) ${ }^{1}$ explained by $G D P C_{t-1}$ (its lagged value). $F S$ is the financial stability indicator (see Sect. 3.2 for details on the variables used to proxy bank distress). LG is the labour growth defined as the number of employed individuals at time $t$ minus the number of employed individuals at time $t-1$ (see also Destefanis et al. 2014; Barra and Ruggiero 2020). TPC is the technology proxy controlling for the local state of the technology and industry structure, measured as the ratio between service workers and the sum of industry plus service workers, divided by the population in each area.

\footnotetext{
1 GDP per worker is constructed by updating the LMA value-added data from ISTAT with data from the Bureau van Dijk AIDA (AIDA is a database providing balance sheets and other information about Italian firms with a turnover of at least one million euro. See for further information: http://aida.bvdep.com/).
} 
$\mathrm{BC}$ is the branch density, controlling for the distribution of banks in the territory and measured as the ratio between branches and the population in each area. ${ }^{2}$ TIME is time dummies, controlling for time-specific effects or unobservable shocks. $\mu$ is the unobserved area-specific effect, and finally, $\varepsilon$ is the disturbance error. Subscripts $i$ and $t$ refer to the area of our analysis (LMA) and time periods (years), respectively. To take into account the characteristics of banks, the percentages of cooperative and commercial banks are included (popular banks as the benchmark group). Macroareas are also included to control for geographic effects, using dummy variables taking the value of 1 in case the bank is located in the north-west, north-east, centre, and southern ${ }^{3}$ areas of the country, respectively (southern region used as the benchmark group), and 0 otherwise. Finally, the structure of the market is also included, using dummy variables taking the value of 1 in case the LMA contains one bank (i.e. monopoly), two banks (i.e. duopoly), three banks (i.e. oligopoly), and more than three banks (i.e. perfect competition), respectively (LMAs with one bank used as the benchmark group) and 0 otherwise.

To eliminate the unobserved area-specific effect $\left(\mu_{i}\right)$ in the dynamic panel specification of the model (where the areas' effects can change over time), we use the twostep system GMM estimator (Arellano and Bond 1991; Arellano and Bover 1995; Blundell and Bond 1998) with corrected standard errors (Windmeijer 2005). To deal with suspected endogeneity between the stability of the financial system and economic development (i.e. for instance changes in the economic conditions could lead to an increase in the demand or supply of loans), we instrument FS including lagged levels and differences. As usual, we check the correctness of the model through the Sargan test of over-identifying restrictions for validity of the instruments. The Arellano-Bond test is used, instead, for testing the zero autocorrelation in the first-differenced errors at order one-AR(1) — and autocorrelation between the errors' terms over time-AR(2). See Table 1 for a description of the variables. In estimating the GMM model, we rely on STATA 13.

\subsection{Measure of financial stability}

A widely used indicator of bank soundness and financial instability is the Z-score (see among others Hesse and Cihak 2007; Laeven and Levine 2009; Unde and Heimeshoff 2009; Chiaramonte et al. 2015). More specifically, to proxy bank insolvency risk, we use two types of $\mathrm{Z}$-score measures based on either the return on assets or the return on equity, represented as ZROA or ZROE, respectively. For each bank $i$ and time $t, Z R O A$ and $Z R O E$ are defined as follows:

$$
Z R O A_{i, t}=\frac{E T A_{i, t}+R O A_{i, t}}{\sigma R O A_{i, t}}
$$

\footnotetext{
3 Southern area also includes the islands.

2 We have also used the branch density as the ratio between branches and square kilometre (as a measure of the accessibility to bank services across locations). Results, available on request, are similar.
} 


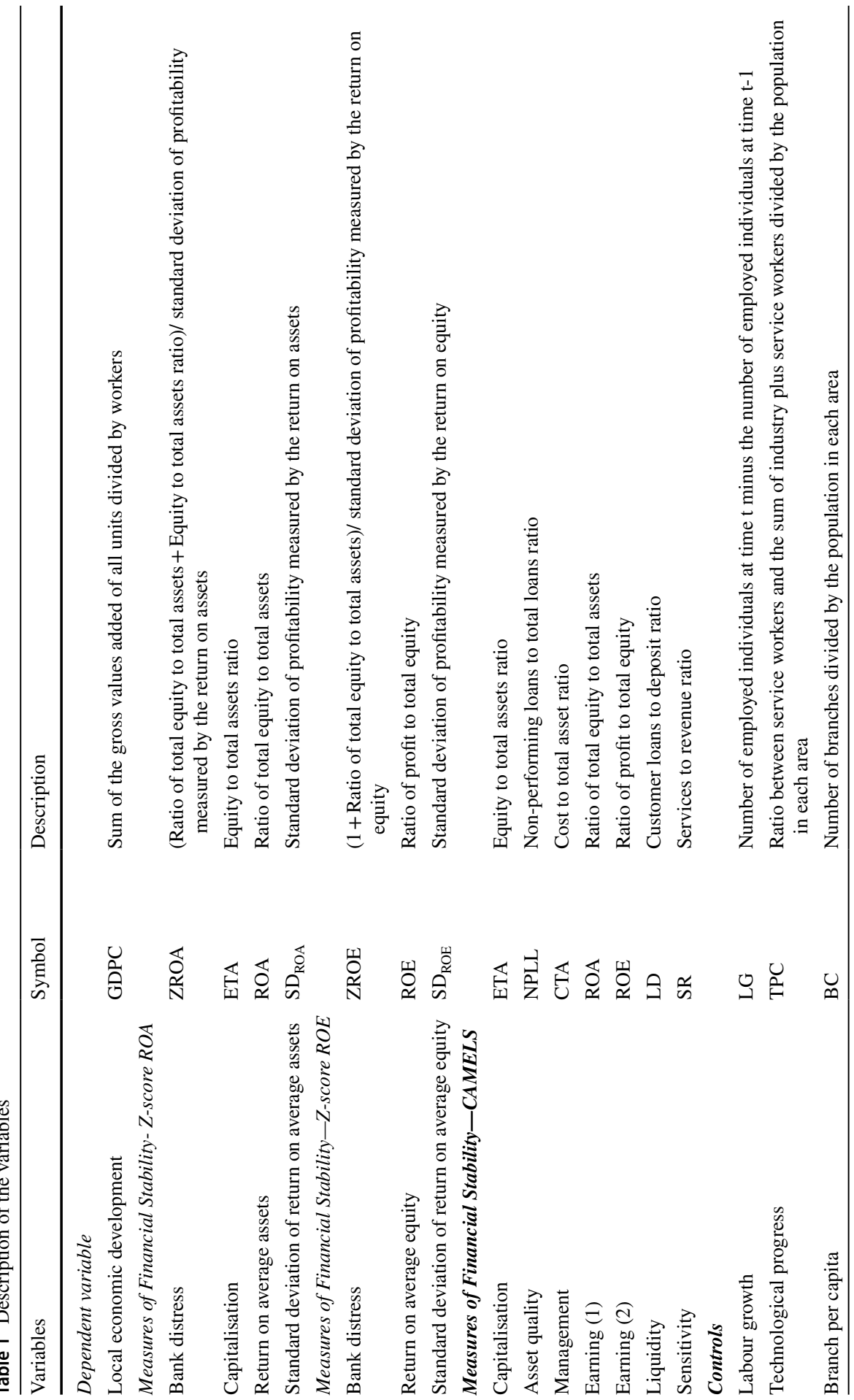




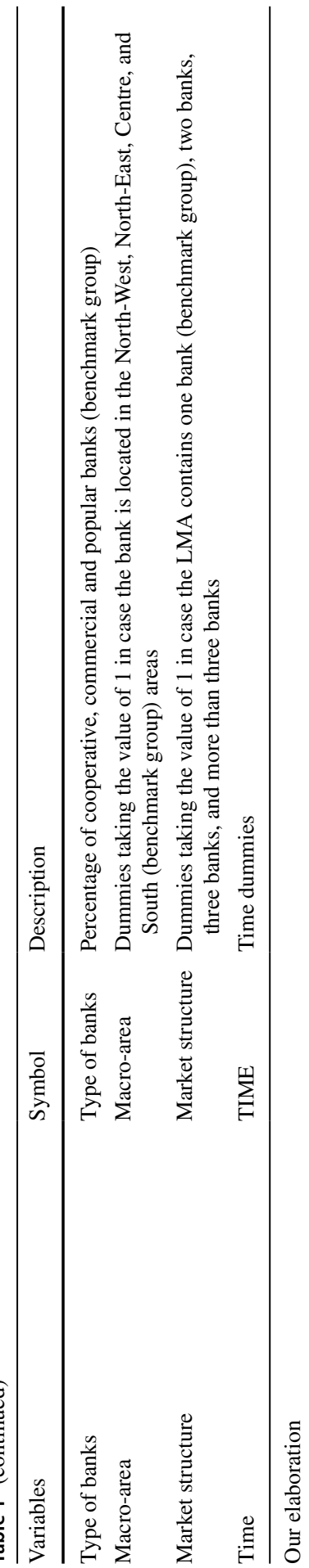




$$
Z R O E_{i, t}=\frac{1+R O E_{i, t}}{\sigma R O E_{i, t}}
$$

where ETA is the level of capitalization of the bank (i.e. equity to total assets). ROA denotes the ratio between profit and total assets (i.e. return on assets). $R O E$ indicates the ratio between profit and total equity (i.e. return on equity). $\sigma R O A$ and $\sigma R O E$ are the standard deviations of the ROA and $R O E$, respectively, in the period analysed. ${ }^{4}$ Following Agoraki et al. (2011) and Soedarmono et al. (2013), $\sigma R O A$ and $\sigma R O E$ at time $t$ are calculated on the basis of observations of $R O A$ and $R O E$, respectively, from time $t$ to $t-2$ (a three-period-based rolling window). They are considered as good proxies of a bank's distance to the default (Rojas-Suarez 2002) and do not require strong assumptions about the distribution of the return on assets (Strobel 2011). Both measures combine banks' buffers (capital and profits) with the risks they face (measured by the standard deviation of returns). More specifically, they reflect the number of standard deviations by which returns would have to fall from the mean in order to wipe out equity. A higher value of Z-score implies a lower probability of insolvency risk (Unde and Heimeshoff 2009) and greater stability (i.e. inverse of the probability of defaults), providing a direct measure of the banking system stability. The Z-score will then increase with the banks' profitability and capital ratio and, instead, decrease with increases in the conditional volatility. Therefore, we expect a positive sign for the relationship between Z-scores (ZROA and ZROE) and economic development. ZROA and ZROE are measured at the bank level and then averaged out at the LMA level.

As an alternative to the Z-score, to capture the financial vulnerability of banks and to predict their distress, we use CAMELS variables (see for instance Poghosyan and Čihák 2011; Chiaramonte et al. 2015). As denoted by the acronym, CAMELS variables measure specific bank characteristics (capital, asset quality, management, earnings, liquidity, and sensitivity to market risk) and indicate the bank's soundness dependent of financial accounting values, assuming that accounting data are a good proxy of bank quality as well as of a bank's financial vulnerability. The first component of the CAMELS variables is a proxy of a bank's capital measured by the ratio of total equity to total assets (ETA). Higher values of ETA mean that banks are more resilient to shocks (i.e. low leverage). We expect a positive sign for the relation between ETA and economic development. A proxy of asset quality is the second covariate inside the CAMELS variables, being the ratio of non-performing loans to total loans (NPLL). The higher the ratio, the lower the quality of the bank's loan portfolio and the higher the probability of bank distress. We expect a negative sign between NPLL and economic development. Managerial quality (third component) is proxied by the ratio of cost to total assets (CTA). Higher values of this ratio indicate low managerial quality and a higher probability of distress. We expect a negative sign between CTA and economic development. As for earnings, the fourth component, it is measured through either ROA or ROE. An increase in profitability reduces

\footnotetext{
${ }^{4}$ Due to its skewness, we use a $\log$ transformation of the Z-score.
} 
the likelihood of a distress event. We expect a positive sign between both ROA and ROE and economic development. Liquidity, the fifth component, is measured by the net (customer) loans to deposit ratio (LD). Higher liquidity may better satisfy firms' and households' demand for financial services. However, higher liquidity may also lead to a higher probability of distress. Indeed, banks that finance large portions of their loan portfolios with short-term liabilities are more exposed to refinancing problems in adverse scenarios. We expect a positive sign between LD and economic development in the former case and a negative sign in the latter. Finally, the sixth component of the CAMELS variables corresponds to the sensitivity to market risk, proxied by the services to revenue ratio (SR). Diversification could lead to a reduction of risks and therefore to a lower probability of insolvency and to greater bank stability. It is also true that a higher dependence on market-related income, instead, might decrease a bank's stability, especially in times of financial market crises. We expect a positive sign between SR and economic development in the former case and, instead, a negative sign in the latter case. Again, CAMELS variables are measured at the bank level and then averaged out at the LMA level.

\subsection{Data}

Data on financial intermediaries are collected from BilBank 2000, distributed by ABI (Associazione Bancaria Italiana). They provide a large time extension and are rich in information on bank balance sheets over the 2001-2012 period (see Table 1 for details on the definition of the variables) ${ }^{5}$

The sample of banks consists of cooperative, commercial and popular banks, excluding branches of banks headquartered abroad. In particular, we use a sample of Italian banks classified by the Bank of Italy as: major (average funds intermediated more than 65 billion euros), large (average funds intermediated between 27 and 65 billion euros), medium (average funds intermediated between 9 and 27 billion euros), small (average funds intermediated between 1.3 and 9 billion euros) and minor (average funds intermediated less than 1.3 billion euros). All monetary aggregates are in thousands of deflated 2005 euros.

Employment is from the ISTAT LMA data set. In addition, the technology proxy (the ratio between service workers and the sum of industry plus service workers) comes from the same source. GDP per worker is constructed by updating the LMA value-added data from ISTAT with data from the Bureau van Dijk AIDA ${ }^{6}$ (see also Destefanis et al. 2014; Barra et al. 2016a, b; Barra and Zotti, 2019). LMA-level data for branches, (non-financial institutions) deposits and loans are from the Bank of Italy (Bollettino Statistico). Table 2 describes the sample used in the analysis by year and geographical location, taking the average of variables for LMA level.

\footnotetext{
5 We do not have information on some of the variables used in the analysis at LMA level for years before 2001 and after 2012.

6 See footnote 1.
} 


\begin{tabular}{|c|}
\hline 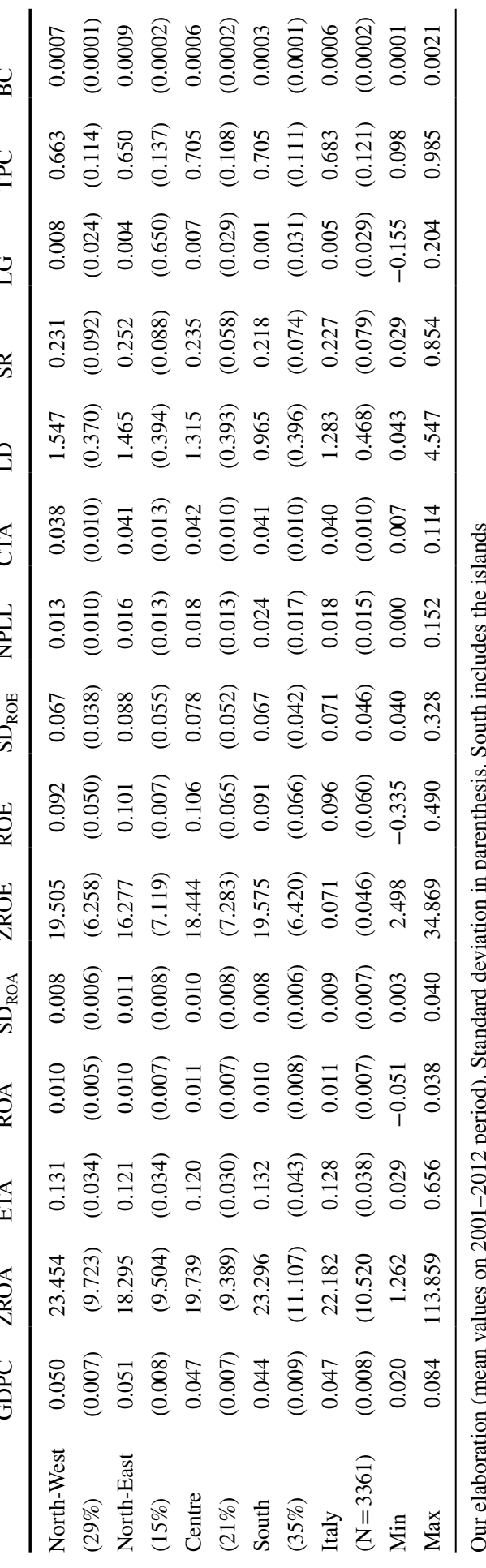 \\
\hline
\end{tabular}


Table 3 Effect of financial stability on local economic development-using Z-score, its components, and CAMELS variables

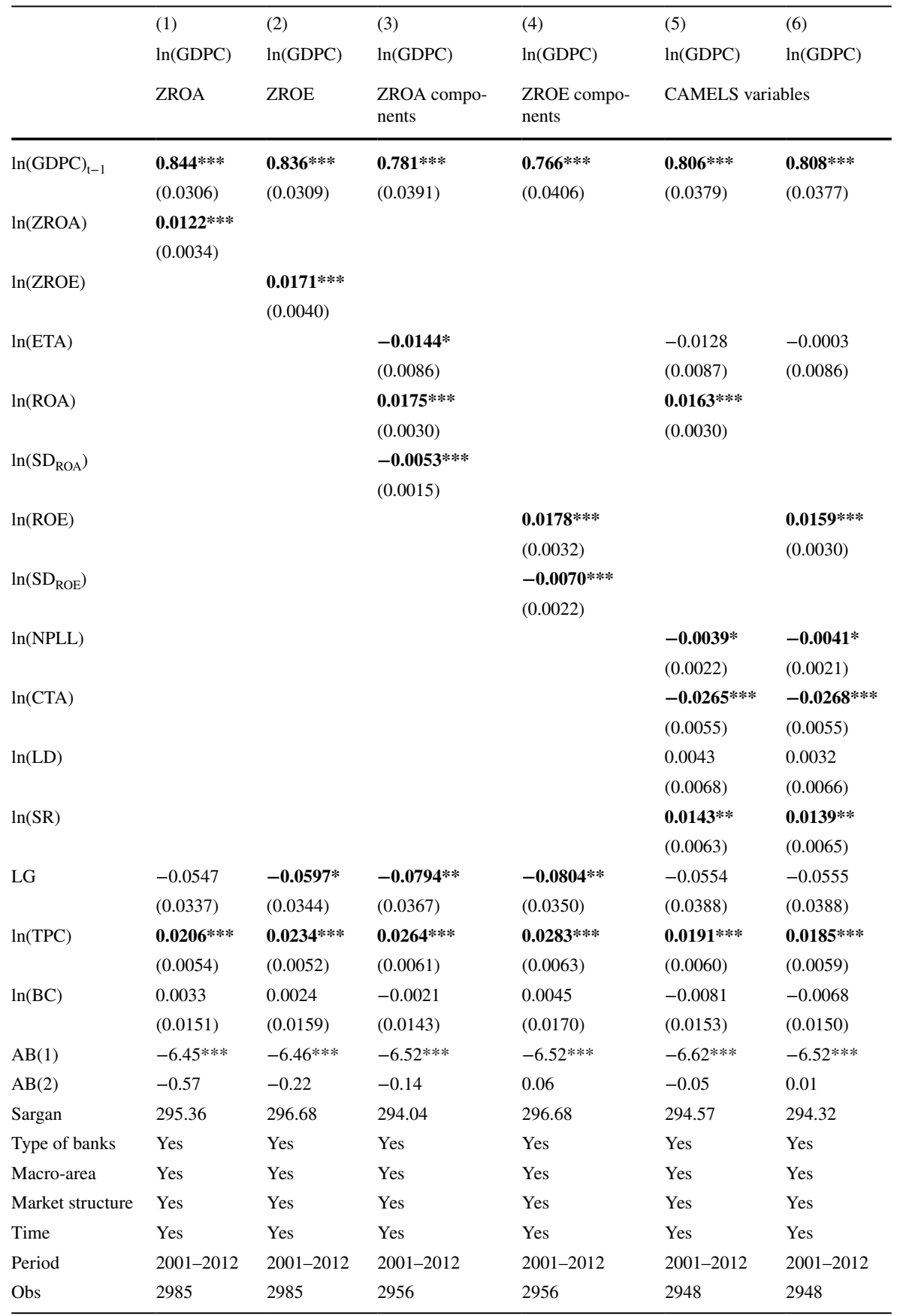

Bold values refer to the coefficients which are statistically significant

Standard errors in brackets; * $p<0.1, * * p<0.05, * * * p<0.01$ 


\section{Empirical evidence}

\subsection{Financial stability-economic development nexus at the LMA level}

The GMM estimates of the local economic growth model are presented in Table 3. All estimates are carried out on the full sample period (2001-2012). As expected due to the lagged dependent term, the Arellano-Bond AR(1) test presents evidence against the null hypothesis of zero autocorrelation in the first-differenced errors at order one. Moreover, both the Sargan and the Arellano-Bond AR(2) tests do not reject $\mathrm{H} 0$, suggesting validity for the over-identifying restrictions and the absence of second-order serial correlation.

The lagged value of GDP per capita (GDPC) has a significant coefficient with positive sign in all models. The log of the Z-score is positive and statistically significant, as predicted, both when the ZROA (Table 3, Column 1) and when the ZROE are used (Table 3, Column 2). The positive relationship between the Z-score and local economic development suggests that greater bank stability (lower probability of insolvency risk as proxied by higher values of Z-scores) fosters economic development of LMAs, through a direct channel of influence. The higher the stability of the system in terms of risk and the ability to allocate resources into good investments, the higher the rate of economic performance of the LMA. To take into account whether the socio-economic environment plays a role in shaping the relationship between bank stability and economic development, we control for a measure of the job market (LG), the local state of technological and industry structure (TPC), and a measure of the bank presence in the territory (BDC). Estimates, for all models, show a positive and significant relationship between technology and local economic development. A high level of technology in the industry sector brings up local economic development.

To explore which source of financial stability contributes the most to economic development, we decompose the financial stability indicator. More specifically, we firstly regress the variable for economic development on the three components of the ZROA: capitalization (equity of total assets), profitability (return on assets), and volatility of profitability (standard deviation of return on assets). Secondly, we use the two components of the ZROE: the ratio between profit and total equity (return on equity) and volatility of profitability (standard deviation of return on equity). When using the components of ZROA (Table 3, Column 3), the positive relationship between bank stability and economic development of LMAs is largely explained by the bank's ROA. The empirical evidence shows the same pattern also when we decompose the ZROE. Indeed, ROE seems to be the main variable explaining the relationship between stability and GDP per capita (Table 3, Column 4). ${ }^{7}$

\footnotetext{
${ }^{7}$ Results are also confirmed when the components of both ZROA and ZROE are individually used. Results are available on request.
} 


\subsection{Do CAMELS-related covariates influence economic development of LMAs?}

Although the Z-score is a recognized measure of bank stability in the literature (see among others Houston et al. 2010; Beck et al. 2012; Fiordelisi and Mare 2014; Chiaromonte et al. 2015), it has also been criticized due to its high dependence on the quality of the accounting framework. Indeed, as banks may smooth the accounting data, the Z-score may turn out to be a too-positive reflection of bank financial stability (Laeven and Majnoni 2003) and a poor measure of bank distress (Poghsoy and Cihak 2011). Therefore, we also present the results by using CAMELS variables as a measure of bank financial stability.

Columns 5 and 6 in Table 3 show that the asset quality measure (NPLL), the proxy for managerial quality (CTA), and the earnings variables (ROA and ROE) are statistically significant with the expected sign. More specifically, the ratio of nonperforming loans to total loans (NPLL) is negative. The higher the ratio, the lower the quality of the bank's portfolio and the higher the probability of bank distress, having negative effects on local economic development. The cost to total assets ratio (CTA) is also negative, confirming that part of the financial stability-economic development nexus goes through the managerial quality of the banks. Indeed, financial institutions with a higher value of cost to total asset ratio have a low managerial quality and a higher probability of distress, having a negative effect on local economic development. The ROA is positive. As expected, the relationship between financial stability and economic development seems to be related to the level of bank profitability. An increase in profitability reduces the likelihood of distress having a positive effect on local economic development. The same positive relationship holds when ROE is used. Finally, the proxy for the sensitivity to market ratio (SR) is positive and statistically significant. Bank diversification of risk could lead to a lower probability of insolvency and to greater bank stability, having positive effects on local economic development. The proxies for liquidity (LD) and for the bank's capital (ETA) are not statistically significant. ${ }^{8}$ Finally, as for the socio-economic environmental characteristics, results confirm a positive and significant relationship between technology (TPC) and local economic development.

\subsection{A further exploration of the results: the role of spillover effects}

We extend the analysis to address potential geographical spillovers. To explore whether geographical space has an impact on the relationship between financial stability and local economic development, we specify a spatial-lag model such that the financial stability of banks can spill over to the area $i$. In other words, we take into account that the development of area $i$ depends systematically on the financial stability development in neighbouring areas $k \in I$, where $I$ is the set of all the areas (Anselin 1988). Geographical data on latitude and longitude of LMAs are used to construct a binary type of spatial weight matrix to weight the financial stability and economic development indicators of

\footnotetext{
${ }^{8}$ Results are also confirmed when the CAMELS variables are individually used. Results are available on request.
} 
Table 4 Effect of financial stability on local economic development - The effects of spatial spillovers

\begin{tabular}{|c|c|c|c|c|c|c|}
\hline & (1) & (2) & (3) & (4) & (5) & (6) \\
\hline & $\ln (\mathrm{GDPC})$ & $\ln (\mathrm{GDPC})$ & $\ln (\mathrm{GDPC})$ & $\ln (\mathrm{GDPC})$ & $\ln (\mathrm{GDPC})$ & $\ln (\mathrm{GDPC})$ \\
\hline & ZROA & ZROE & ZROA & ZROE & $\begin{array}{l}\text { ZROA compo- } \\
\text { nents }\end{array}$ & $\begin{array}{l}\text { ZROE com- } \\
\text { ponents }\end{array}$ \\
\hline \multirow[t]{2}{*}{$\ln (\mathrm{GDPC})_{\mathrm{t}--1}$} & $0.842 * * *$ & $0.838 * * *$ & $0.666 * * *$ & $0.576 * * *$ & $0.838 * * *$ & $0.836 * * *$ \\
\hline & $(0.0391)$ & $(0.030)$ & $(0.0293)$ & $(0.0394)$ & $(0.266)$ & $(0.0312)$ \\
\hline \multirow[t]{2}{*}{$\ln (\mathrm{GDPC})_{\mathrm{t}-1} * \mathrm{~W}$} & & & $0.469 * * *$ & $0.528 * * *$ & -0.0013 & -0.0012 \\
\hline & & & $(0.0617)$ & $(0.0515)$ & $(0.0077)$ & $(0.0009)$ \\
\hline \multirow[t]{2}{*}{$\ln (\mathrm{ZROA})$} & $0.0123 * * *$ & & $0.0262 * * *$ & & 0.0130 & \\
\hline & $(0.0039)$ & & $(0.0037)$ & & $(0.102)$ & \\
\hline \multirow[t]{2}{*}{$\ln (\mathrm{ZROA}) * \mathrm{~W}$} & -0.155 & & & & -0.0014 & \\
\hline & $(0.134)$ & & & & $(0.0083)$ & \\
\hline \multirow[t]{2}{*}{$\ln (\mathrm{ZROE})$} & & $0.0160 * * *$ & & -0.0750 & & $0.0173 * * *$ \\
\hline & & $(0.0039)$ & & (7.644) & & $(0.0038)$ \\
\hline \multirow[t]{2}{*}{$\ln (\mathrm{ZROE}) * \mathrm{~W}$} & & $-0.162 * * *$ & & & & -0.0013 \\
\hline & & $(0.0445)$ & & & & $(0.0010)$ \\
\hline \multirow[t]{2}{*}{ LG } & -0.0546 & $-0.0646^{*}$ & & & -0.0585 & $-0.0633^{*}$ \\
\hline & $(0.0546)$ & $(0.0345)$ & & & $(0.589)$ & $(0.0360)$ \\
\hline \multirow[t]{2}{*}{$\ln (\mathrm{TPC})$} & $0.0196 * *$ & $0.0230 * * *$ & & & 0.0212 & $0.0230 * * *$ \\
\hline & $(0.0090)$ & $(0.0052)$ & & & $(0.103)$ & $(0.0055)$ \\
\hline \multirow[t]{2}{*}{$\ln (\mathrm{BC})$} & 0.0071 & 0.0083 & & & 0.0018 & 0.0001 \\
\hline & $(0.0444)$ & $(0.0160)$ & & & $(0.580)$ & $(0.016)$ \\
\hline $\mathrm{AB}(1)$ & $-6.45^{* * *}$ & $-6.47 * * *$ & $-6.43 * * *$ & $-6.46^{* * *}$ & $-2.16^{* * *}$ & $-6.47 * * *$ \\
\hline $\mathrm{AB}(2)$ & -0.53 & -0.21 & -0.53 & -0.22 & -0.12 & -0.20 \\
\hline Sargan & 297.95 & 296.28 & 313.29 & 296.67 & 270.38 & 284.54 \\
\hline Type of banks & Yes & Yes & Yes & Yes & Yes & Yes \\
\hline Macro-area & Yes & Yes & Yes & Yes & Yes & Yes \\
\hline Market structure & Yes & Yes & Yes & Yes & Yes & Yes \\
\hline Time & Yes & Yes & Yes & Yes & Yes & Yes \\
\hline Period & 2001-2012 & 2001-2012 & 2001-2012 & 2001-2012 & 2001-2012 & 2001-2012 \\
\hline Obs & 2985 & 2985 & 2985 & 2985 & 2985 & 2985 \\
\hline
\end{tabular}

Bold values refer to the coefficients which are statistically significant

Standard errors in brackets; $* p<0.1, * * p<0.05, * * * p<0.01$

all neighbouring areas. The unit of distance is kilometres (see Kondo 2017). More specifically, we firstly add to Eq. (1) the term $\left(\ln F S_{i, t} * W\right)$, which is the weighted average of bank financial stability across $I_{i}$ areas' neighbouring area $i$. Its coefficient measures whether economic development at the LMA level indirectly benefits, suffers, or is independent from the bank financial stability (due to the presence of banks with a high level of financial stability) of neighbours. Secondly, we add to Eq. (1) the term $\ln G D P C_{i, t} * W$, which is the weighted average GDPC across $I_{i}$ areas' neighbouring area $i$. It is included to control for spillovers due to the economic development of neighbouring areas. 
Table 4 summarizes the results. We first use the weighted average of bank financial stability across areas' neighbouring area $i$ (Table 4, Columns 1 and 2). Table 4, Column 1 , shows that financial stability promotes economic performance. However, economic development at the LMA level does not depend on the bank financial stability of neighbours as proxied by bank ROA. When we measure, instead, bank financial stability with ROE, we still find that a higher degree of stability in the banking system is associated with an increase in economic development. However, we also find a negative and statistically significant coefficient on the spatial weighted variable, meaning that economic development at the LMA level suffers from the bank financial stability of neighbours (Table 4, Column 2). There is not a straightforward theoretical prediction of the spatial effects. Indeed, a positive coefficient could be expected in the case that better conditions of the banking system in neighbouring areas might also contribute to increase an area's growth by incentivizing real economic interaction. A negative coefficient could be, instead, expected if better financial conditions of the banking system in neighbouring areas may attract investments over the border and therefore have a detrimental effect on an area's growth. The negative and statistically significant coefficient on the spatial weighted bank financial stability suggests that having more efficient banking services in the geographic vicinity generates a pull effect due to the possibility that borrowers and investors may be attracted to such nearby banking services, take out credit, and consume in neighbouring areas (see also Hasan et al. 2009 for a similar result). Columns 3 and 4 in Table 4 summarize the results for the weighted average GDPC across areas' neighbouring area $i$, showing that an area benefits, in terms of economic development, from being close to a prosperous area. Finally, we add all factors together. Results, summarized in Table 4, Columns 5 and 6, do not show evidence that geographical space has an impact on the relationship between financial stability and economic development. However, the empirical evidence also indicates that the spatial effects do not modify the main conclusions - that financial stability fosters economic performance of LMAs (at least when ZROE is used to proxy bank soundness).

\section{Sensitivity test and robustness of empirical results}

We performed a number of tests to further explore the results.

Firstly, we examine whether the results depend on the distribution of the financial stability by focussing on the banks at different tertiles of the bank financial distress proxies. Table 5 summarizes the results for ZROA (Columns 1-3, at 1st, 2nd, and 3rd tertile of ZROA) and ZROE (Columns 4-6, at 1st, 2nd, and 3rd tertile of ZROE), showing that both proxies of banks' financial stability have a direct positive and significant effect on local economic development when banks with a value of stability in the 1st and 2nd tertiles are considered. The result may be explained by the intuition of an "optimal" financial stability level; the effect of financial stability seems to be not relevant for growth if the level of stability is higher than this level (assuming that this level is around the 2nd tertile observed in the sample).

Secondly, we examine whether the results depend on the distribution of the measure of the economic development. To explore this issue, we use a two-step with fixed effects quantile regression (Canay 2011) and estimate the effects of financial stability of banks 
Table 5 Effect of financial stability (1st, 2nd, and 3rd tertile) on local economic development

\begin{tabular}{|c|c|c|c|c|c|c|}
\hline & (1) & (2) & (3) & (4) & (5) & (6) \\
\hline & $\ln (\mathrm{GDPC})$ & $\ln (\mathrm{GDPC})$ & $\ln (\mathrm{GDPC})$ & $\ln (\mathrm{GDPC})$ & $\ln (\mathrm{GDPC})$ & $\ln (\mathrm{GDPC})$ \\
\hline & ZROA & & & ZROE & & \\
\hline & 1st tertile & 2nd tertile & 3rd tertile & 1st tertile & 2nd tertile & 3rd tertile \\
\hline $\ln (\text { GDPC })_{t-1}$ & $0.862 * * *$ & $0.932 * * *$ & $0.713 * * *$ & $0.701 * * *$ & $0.934 * * *$ & $0.724 * * *$ \\
\hline & $(0.0426)$ & $(0.0216)$ & $(0.0562)$ & $(0.0526)$ & $(0.0267)$ & $(0.0599)$ \\
\hline $\ln (\mathrm{ZROA})$ & $0.0230 * * *$ & $0.0157 * *$ & -0.00732 & & & \\
\hline & $(0.00448)$ & $(0.00672)$ & $(0.00717)$ & & & \\
\hline $\ln (\mathrm{ZROE})$ & & & & $0.0565 * * *$ & $0.0355 * * *$ & -0.0267 \\
\hline & & & & $(0.00565)$ & $(0.0121)$ & $(0.0208)$ \\
\hline LG & $-0.136^{*}$ & -0.0470 & -0.0206 & -0.0111 & $-0.201 * * *$ & -0.0772 \\
\hline & $(0.0725)$ & $(0.0551)$ & $(0.0560)$ & $(0.0581)$ & $(0.0486)$ & $(0.0639)$ \\
\hline $\ln (\mathrm{TPC})$ & $0.0174 * *$ & $0.0288 * * *$ & $0.0367 * * *$ & 0.0104 & $0.0268 * * *$ & -0.0130 \\
\hline & $(0.00834)$ & $(0.00866)$ & $(0.0127)$ & $(0.0105)$ & $(0.00637)$ & $(0.0549)$ \\
\hline $\ln (\mathrm{BC})$ & 0.00726 & 0.000695 & -0.0226 & 0.0208 & -0.000277 & 0.00422 \\
\hline & $(0.0209)$ & $(0.0165)$ & $(0.0247)$ & $(0.0295)$ & $(0.0195)$ & $(0.0324)$ \\
\hline $\mathrm{AB}(1)$ & $-5.65^{* * *}$ & $-5.91 * * *$ & $-2.79 * * *$ & $-6.34 * * *$ & $-4.83 * * *$ & $-4.58 * * *$ \\
\hline $\mathrm{AB}(2)$ & -1.13 & 1.27 & -0.17 & 0.56 & -0.03 & -1.37 \\
\hline Sargan & 170.25 & 217.19 & 211.60 & 125.97 & 203.6 & 199.69 \\
\hline Type of banks & Yes & Yes & Yes & Yes & Yes & Yes \\
\hline Macro-area & Yes & Yes & Yes & Yes & Yes & Yes \\
\hline Market structure & Yes & Yes & Yes & Yes & Yes & Yes \\
\hline Time & Yes & Yes & Yes & Yes & Yes & Yes \\
\hline Period & 2001-2012 & 2001-2012 & 2001-2012 & 2001-2012 & 2001-2012 & 2001-2012 \\
\hline Obs & 908 & 1003 & 1074 & 975 & 940 & 1070 \\
\hline
\end{tabular}

Bold values refer to the coefficients which are statistically significant

Standard errors in brackets; $* p<0.1$, ** $p<0.05$, *** $p<0.01$

on local economic development at different percentiles of GDP. Table 6 summarized the results when ZROA (Columns 1-5, at the 25th, 50th, 75th, 90th, and 95th percentile of GDP) and ZROE (Columns 6-10, at the 25th, 50th, 75th, 90th, and 95th percentile of GDP) are used as proxies of financial distress. The empirical evidence shows that banks' financial stability has a direct positive and significant effect on local economic development, especially at the highest quantiles of the economic development distribution. This reveals the presence of virtuous circles characterized by stable banks, located in the territories that grow more, which in turn act as a stimulus to reach higher levels of operations.

Thirdly, we also explore the potential role of the latest financial crisis that could affect the second part of the period under scrutiny. We estimate again the main model and add a dummy variable (CRISIS), taking the value of 1 in years after 2007, and 0 otherwise. The results, summarized in Table 7, Columns 1 and 2, are similar and suggest that greater uncertainty due to the financial crisis lowers economic development of LMAs (negative and statistical coefficient of the dummy 


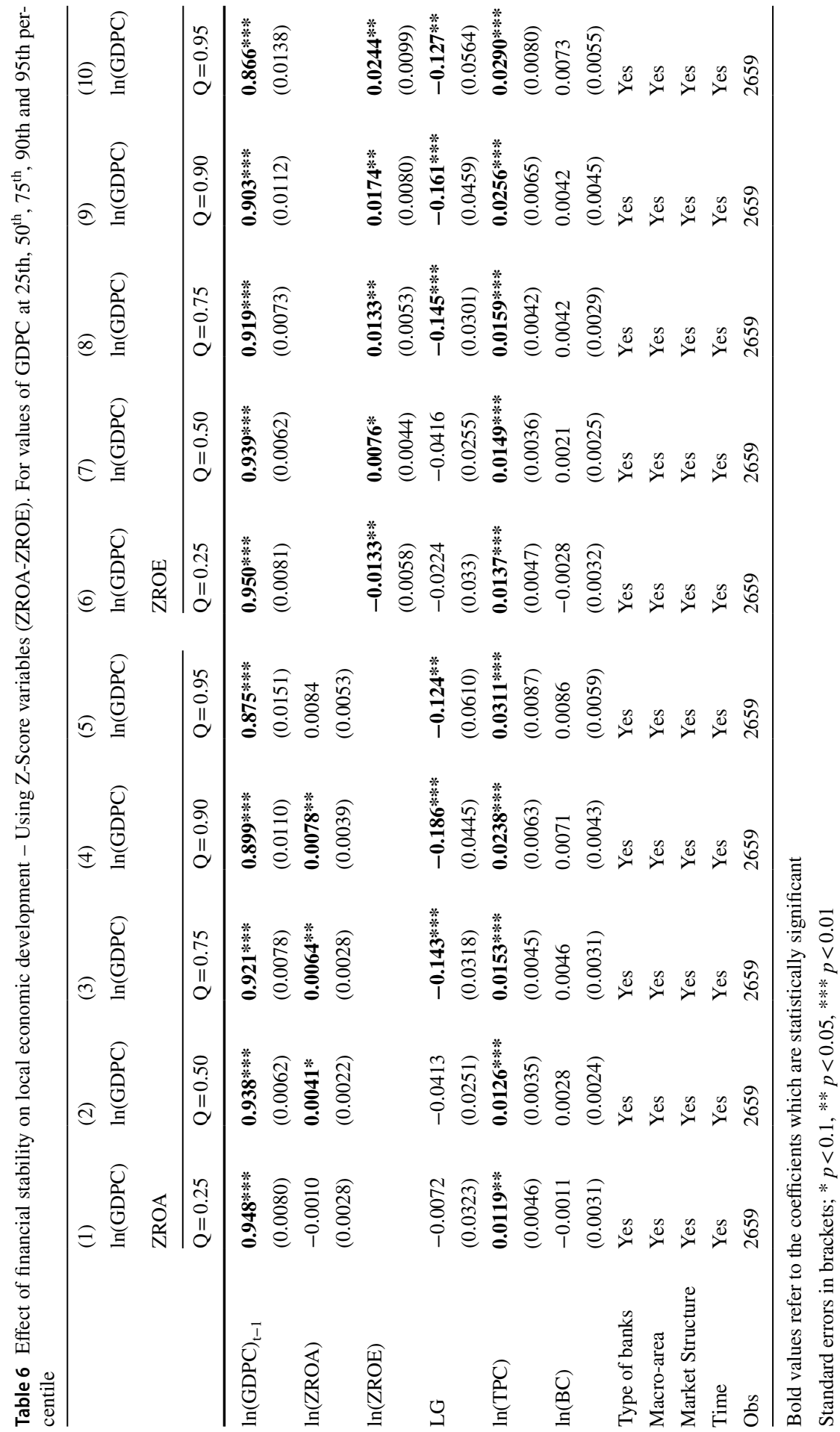


Table 7 Effect of financial stability on local economic development - The effect of the crisis

\begin{tabular}{|c|c|c|c|c|}
\hline & (1) & (2) & (3) & (4) \\
\hline & $\ln (\mathrm{GDPC})$ & $\ln (\mathrm{GDPC})$ & $\ln (\mathrm{GDPC})$ & $\ln (\mathrm{GDPC})$ \\
\hline & ZROA & ZROE & ZROA & ZROE \\
\hline \multirow[t]{2}{*}{$\ln (\mathrm{GDPC})_{\mathrm{t}-1}$} & $0.804 * * *$ & $0.820 * * *$ & $0.808 * * *$ & $0.819 * * *$ \\
\hline & $(0.0305)$ & $(0.0311)$ & $(0.0298)$ & $(0.0297)$ \\
\hline \multirow[t]{2}{*}{$\ln (\mathrm{ZROA})$} & $0.0198 * * *$ & & $0.0149 * * *$ & \\
\hline & $(0.0033)$ & & $(0.00394)$ & \\
\hline \multirow[t]{2}{*}{$\ln (\mathrm{ZROA}) *$ CRISIS } & & & $0.0084 * * *$ & \\
\hline & & & $(0.00264)$ & \\
\hline \multirow[t]{2}{*}{$\ln (\mathrm{ZROE})$} & & $0.0122 * * *$ & & $0.0126 * * *$ \\
\hline & & $(0.0038)$ & & $(0.00417)$ \\
\hline \multirow[t]{2}{*}{$\ln (\mathrm{ZROE}) * \mathrm{CRISIS}$} & & & & $0.0168 * * *$ \\
\hline & & & & $(0.00357)$ \\
\hline \multirow[t]{2}{*}{ LG } & $-0.0682 * *$ & $-0.0840 * *$ & $-0.0667 * *$ & $-0.0776 * *$ \\
\hline & $(0.0321)$ & $(0.0332)$ & $(0.0330)$ & $(0.0333)$ \\
\hline \multirow[t]{2}{*}{$\ln (\mathrm{TPC})$} & $0.0283 * * *$ & $\mathbf{0 . 0 3 3 3} * * *$ & $0.0263 * * *$ & $0.0284 * * *$ \\
\hline & $(0.0059)$ & $(0.0056)$ & $(0.00620)$ & $(0.00727)$ \\
\hline \multirow[t]{2}{*}{$\ln (\mathrm{BC})$} & $0.0243 *$ & $0.0284 *$ & $0.0322 * *$ & $0.0338 * *$ \\
\hline & $(0.0141)$ & $(0.0152)$ & $(0.0149)$ & $(0.0155)$ \\
\hline \multirow[t]{2}{*}{ CRISIS } & $-0.0407 * * *$ & $-0.0381 * * *$ & $-0.0669 * * *$ & $-0.0878 * * *$ \\
\hline & $(0.0019)$ & $(0.0018)$ & $(0.00849)$ & $(0.0109)$ \\
\hline \multicolumn{2}{|l|}{ Interaction test } & & $10.14 * * *$ & $22.10 * * *$ \\
\hline $\mathrm{AB}(1)$ & $-6.64 * * *$ & $-6.70 * * *$ & $-6.64 * * *$ & $-6.70^{* * *}$ \\
\hline $\mathrm{AB}(2)$ & 1.69 & 1.38 & 1.78 & 1.28 \\
\hline Sargan & 294.04 & 293.25 & 287.26 & 294.50 \\
\hline Type of banks & Yes & Yes & Yes & Yes \\
\hline Macro-area & Yes & Yes & Yes & Yes \\
\hline Market Structure & Yes & Yes & Yes & Yes \\
\hline Time & Yes & Yes & Yes & Yes \\
\hline Period & 2001-2012 & 2001-2012 & 2001-2012 & 2001-2012 \\
\hline Obs & 2985 & 2985 & 2985 & 2985 \\
\hline
\end{tabular}

Bold values refer to the coefficients which are statistically significant

Standard errors in brackets; * $p<0.1$, ** $p<0.05$, *** $p<0.01$

Interaction test for the null hypothesis that $\mathrm{H}_{0}=\mathrm{ZROA} / \mathrm{ZROE} * \mathrm{CRISIS}=0$

CRISIS in all models). To further explore the role of the crisis, we also interact the CRISIS variable with the stability measures. Both when ZROA and ZROE are used as proxies of bank soundness (Table 7, Columns 3 and 4), the empirical evidence suggests that the financial stability of banks has an additional positive and significant effect on local economic development in the years after the crisis. This result could be consistent with the idea that financial stability is important for promoting economic performance even more in the years following the latest financial crisis. 


\section{Summary and concluding remarks}

Financial markets are properly defined at the local level, where legal and institutional characteristics are more homogenous. This study empirically addresses the relationship between financial stability of the banking system and economic development of LMAs in Italy. The idea that the financial system may contribute to the social economic and cultural development of the area in which banks are located has been discussed in the literature. However, only a few quantitative estimates regarding the impact of the banking system's level of distress on the community are present. To the best of our knowledge, this is the first attempt to explore the finance stability-growth nexus using banks operating over a geographically restricted area such as LMAs, where the bulk of the labour force lives and works. More stable banks can exert a positive role over the territory in several ways. They improve the efficiency in the allocation of savings across investment loans. They produce better information through long and strong lending relationships. Financing entrepreneurs engaged in research and development activities and decreasing the costs of financing spending for firms and households are important channels. To shed more light on this relevant topic, we have focused on the Italian experience, using a rich sample of banks over the 2001-2012 period and employing a two-step system GMM estimator.

The empirical results highlight that a higher degree of stability in the banking system is associated with an increase in the economic development of LMAs. Therefore, financial stability promotes and positively predicts a high level of economic performance. Results are stable to different indicators of bank soundness and financial instability. The positive relationship between bank stability and local economic development is explained, mainly, by the bank's return on average assets and equity. A higher ratio between profit and total assets/total equity is related to a higher level of capitalization and, therefore, to greater economic development. Moreover, a higher level of a bank's return on average assets and equity increases the ability to allocate resources into good investments or projects (i.e. helping firms and households in financing spending), positively affecting the rate of economic development of a certain area. Several components capturing banks' financial stability, such as asset quality (non-performing loans to total loans ratio), managerial quality (cost to total assets), a measure of earnings (return on average assets or equity), and sensitivity to market risk (services to revenue ratio), have important effects on local economic development. The presence of spatial effects is tested. Our findings reveal that better financial conditions of the banking system in neighbouring areas have a detrimental effect on an area's growth, possibly attracting investments over the border.

Our analysis could suffer from some limitations and some potential concerns.

First, the use of such a fine territorial stratification (LMAs) minimizes the differences in legal and regulatory exogenous factors affecting financial development. LMAs are somehow representative of the local labour market. It is also true, however, that this study indirectly assumes that local financial markets coincide with local labour markets. This is a strong assumption, as, for instance, an important process for a firm such as that of borrowing could be satisfied by exploring the financial market nearby its local LMAs. A second possible concern regards the Arellano-Bond system GMM model and the influence that spatial dependence might 
have on the covariance estimators. Indeed, in the case of spatial dependence, the GMM model may not produce a consistent estimation of the standard errors of the coefficients. In particular, when a spatial lag of the dependent variable is included in the model, a consistent estimation is based on the maximization of a compressed likelihood, and the Windmeijer correction might not be enough to solve the problem. An alternative strategy would be relying on a fixed effects panel model with spatially dependent variables (i.e. Millo and Piras 2012), which is able to treat the special dependence appropriately. However, in this way, we would not be able to take into account the more than suspected endogeneity problem between financial stability and economic growth (see also Hasan et al. 2009, who applied the same procedure in the financial environment). Finally, a further limitation is that we rely only on LMAs where at least one bank branch is present. This means that all the local systems without banks are excluded from the analysis, leading to a more discontinuous sample. Indeed, it could be argued that we are not considering firms operating in the systems without bank borrowing. In other words, the presence of at least one branch of a bank could be endogenous. To solve this issue, a larger territorial aggregation could be used which would cover all the country's regions. However, LMAs have long been recognized as relevant for assessing the effectiveness of local policy decisions and are, in our opinion, a useful and harmonized geographical disaggregation to impart an intra-regional approach to financial market research.

Keeping these concerns in mind, this article contributes to the limited existing research, shedding further light on the effects that the financial stability of banks might have on raising the ratio of local income per capita, and also including the spatial structure in the analysis. Financial stability, occurring when the banking system works in terms of health and governance, may ensure social welfare and may promote regional and sub-regional development. When the financial system is healthy and stable, financial intermediaries can grant loans to households and businesses more easily in order to increase investments in the area. Consequently, an increase in the volume of goods and services is generated, in turn improving economic development. Indeed, financial stability may be considered as a public good, having a negative effect on social welfare and economic growth when risks are not regularly checked. This means that the provision of financial stability cannot be ensured only by private decisions and requires regulation and supervision of a common agency to be delivered. In other words, it will not be provided if left solely to the market and policy makers as well as regulators need to ensure the smooth functioning of the banking system in order to promote local economic development. An important step towards the regulation of financial institutions is necessary, to monitor systematic risks and to make the stability of the banking system an important prerequisite for sustainable economic growth. Ensuring the health of the financial system is a public policy to avoid situations where instability generates negative externalities.

\section{Appendix}

See Tables 8, 9 and 10 . 
Table 8 LMAs characteristics by regions and territorial location

\begin{tabular}{|c|c|c|c|c|c|}
\hline $\begin{array}{l}\text { Regions (NUTS } 2 \\
\text { level) }\end{array}$ & LMAs & Municipalities & $\begin{array}{l}\text { Resident popula- } \\
\text { tion }\end{array}$ & $\begin{array}{l}\text { Individual work- } \\
\text { ing } \\
\text { in LMAs }\end{array}$ & $\begin{array}{l}\text { Individual living } \\
\text { and working in } \\
\text { LMAs }\end{array}$ \\
\hline Piemonte & 37 & 1204 & $4,223,735$ & $1,462,895$ & $1,448,909$ \\
\hline Valle d'Aosta & 3 & 78 & 123,803 & 44,553 & 44,906 \\
\hline Lombardia & 58 & 1531 & $9,003,080$ & $3,284,776$ & $3,298,014$ \\
\hline $\begin{array}{l}\text { Trentino-Alto } \\
\text { Adige }\end{array}$ & 33 & 341 & 946,446 & 334,425 & 334,678 \\
\hline Veneto & 34 & 581 & $4,502,412$ & $1,613,435$ & $1,609,156$ \\
\hline $\begin{array}{l}\text { Friuli-Venezia } \\
\text { Giulia }\end{array}$ & 11 & 217 & $1,196,720$ & 411,966 & 412,921 \\
\hline Liguria & 16 & 237 & $1,558,790$ & 462,621 & 465,877 \\
\hline Emilia-Romagna & 41 & 356 & $4,025,358$ & $1,472,306$ & $1,476,901$ \\
\hline Toscana & 53 & 290 & $3,512,420$ & $1,174,511$ & $1,172,133$ \\
\hline Umbria & 17 & 90 & 823,603 & 261,501 & 256,947 \\
\hline Marche & 33 & 248 & $1,467,679$ & 492,586 & 492,622 \\
\hline Lazio & 25 & 381 & $5,115,887$ & $1,547,496$ & $1,554,765$ \\
\hline Abruzzo & 19 & 302 & $1,255,603$ & 359,708 & 359,601 \\
\hline Molise & 9 & 138 & 324,175 & 83,176 & 83,709 \\
\hline Campania & 54 & 548 & $5,693,038$ & $1,143,501$ & $1,138,064$ \\
\hline Puglia & 44 & 254 & $4,016,240$ & 896,000 & 890,954 \\
\hline Basilicata & 19 & 128 & 588,476 & 142,598 & 148,761 \\
\hline Calabria & 58 & 410 & $2,017,408$ & 409,916 & 408,888 \\
\hline Sicilia & 77 & 390 & $4,968,991$ & $1,014,431$ & $1,014,588$ \\
\hline Sardegna & 45 & 377 & $1,631,880$ & 410,411 & 410,418 \\
\hline North-West & 114 & 3050 & $1.49 \mathrm{e}+07$ & $5,254,845$ & $5,257,706$ \\
\hline North-East & 119 & 1495 & $1.07 \mathrm{e}+07$ & $3,832,132$ & $3,833,656$ \\
\hline Centre & 128 & 1009 & $1.09 \mathrm{e}+07$ & $3,476,094$ & $3,476,467$ \\
\hline South & 203 & 1780 & $1.39 \mathrm{e}+07$ & $3,034,899$ & $3,029,977$ \\
\hline Island & 122 & 767 & $6,600,871$ & $1,424,842$ & $1,425,006$ \\
\hline Italy & 686 & 8101 & $5.70 \mathrm{e}+07$ & $1.70 \mathrm{e}+07$ & $1.70 \mathrm{e}+07$ \\
\hline
\end{tabular}

Our elaboration

Table 9 Number of LMAs in the sample and in Italy by territorial location

\begin{tabular}{lllll}
\hline $\begin{array}{l}\text { Macro-areas of the } \\
\text { country }\end{array}$ & $\begin{array}{l}\text { LMAs covered in our } \\
\text { sample 2001-2012 }\end{array}$ & $\begin{array}{l}\text { LMAs in Italy in } \\
2001\end{array}$ & $\begin{array}{l}\text { LMAs in } \\
\text { Italy in } \\
2001-2012\end{array}$ & Our coverage (\%) \\
\hline North-West & 626 & 114 & 1368 & 45.76 \\
North-East & 898 & 119 & 1428 & 62.88 \\
Centre & 726 & 128 & 1536 & 47.26 \\
South & 1111 & 325 & 3900 & 28.49 \\
Italy & 3361 & 686 & 8232 & 41.93 \\
\hline
\end{tabular}

Our elaboration 


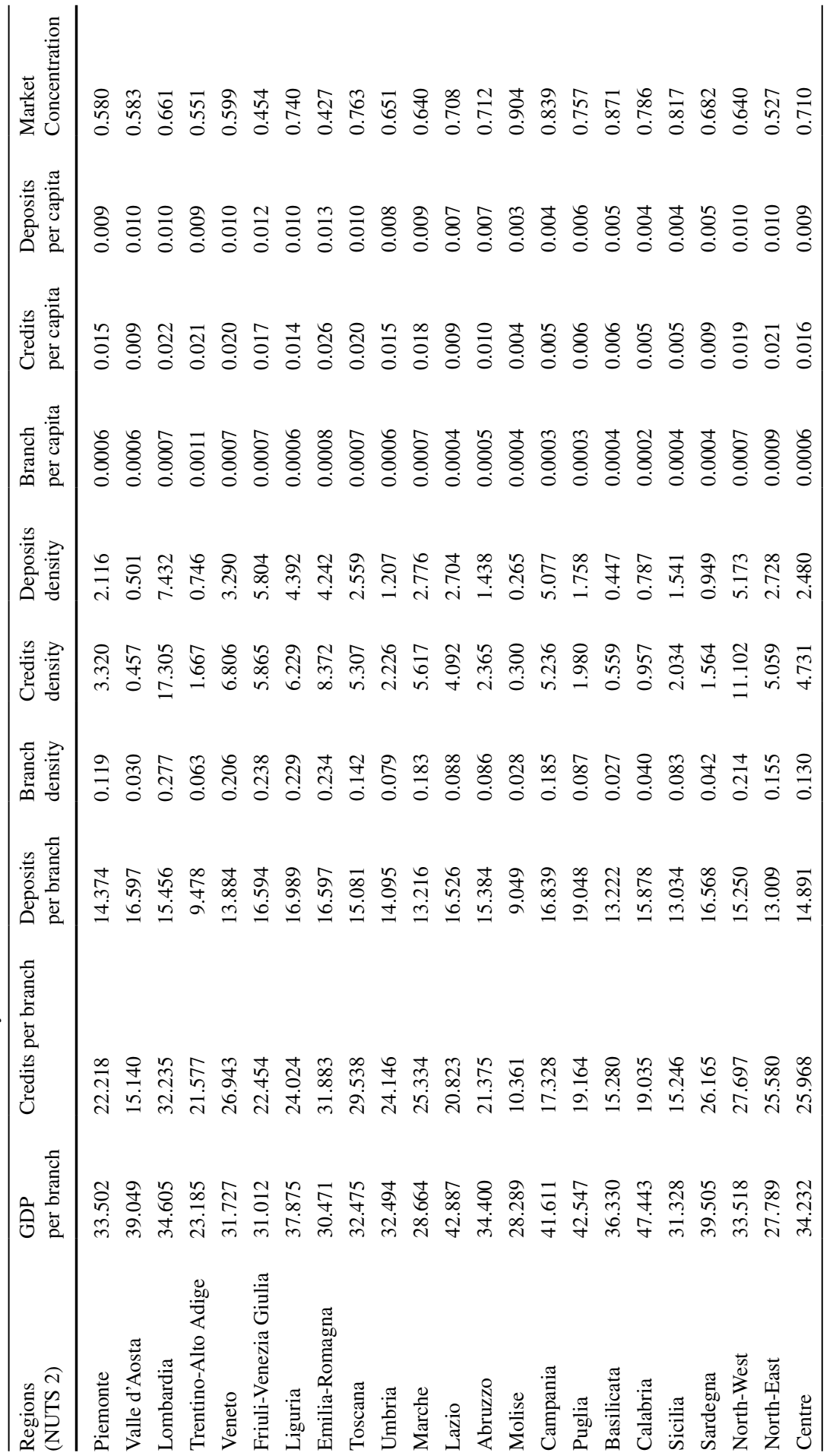




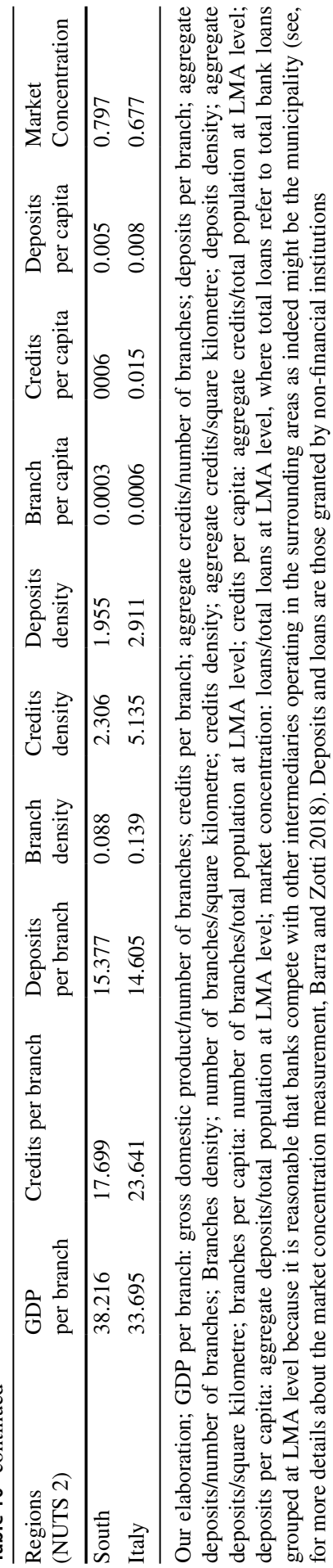


Funding Open access funding provided by Università degli Studi di Torino within the CRUI-CARE Agreement. No funding was used for this paper.

\section{Declarations}

Conflict of interest All authors declare that they have no conflict of interest.

Ethical approval This article does not contain any studies with human participants or animals performed by any of the authors.

Open Access This article is licensed under a Creative Commons Attribution 4.0 International License, which permits use, sharing, adaptation, distribution and reproduction in any medium or format, as long as you give appropriate credit to the original author(s) and the source, provide a link to the Creative Commons licence, and indicate if changes were made. The images or other third party material in this article are included in the article's Creative Commons licence, unless indicated otherwise in a credit line to the material. If material is not included in the article's Creative Commons licence and your intended use is not permitted by statutory regulation or exceeds the permitted use, you will need to obtain permission directly from the copyright holder. To view a copy of this licence, visit http://creativecommons.org/licen ses/by/4.0/.

\section{References}

Aghion P, Fally T, Scarpetta S (2007) Credit constraints as a barrier to the entry and post-entry growth of firms. Econ Policy 22:731-779

Agoraki MEK, Delis MD, Pasiouras F (2011) Regulations, competition and bank risk-taking in transition countries. J Financ Stab 7(1):38-48

Anselin L (1988) Spatial econometrics: methods and models. Kluwer, Dordrecht

Antzoulatos A, Thanopoulos J (2008) Financial system structure and change- - 1986-2005 evidence from the OECD Countries. J Econ Integr 23:977-1001

Arellano M, Bover O (1995) Another look at the instrumental-variable estimation of error-components models. J Econm 68:29-51

Arellano M, Bond S (1991) Some tests of specification for panel data: Monte Carlo evidence and an application to employment equations. Rev Econ Stud 58:277-297

Arestis P, Demetriades P, Luintel K (2001) Financial development and economic growth: the role of stock markets. J Money Credit Bank 33(1):16-41

Barra C, Bimonte G, Zotti R (2016a) On the relationship among efficiency, capitalization and risk: does management matter in local banking market? Appl Econ 48(41):3912-3934

Barra C, Destefanis S, Lubrano Lavadera G (2016b) Risk and regulation: a difference-in-differences analysis for Italian local banks. Financ Res Lett 17(41):25-32

Barra C, Zotti R (2019) Bank performance, financial stability and market concentration: evidence from cooperative and non-cooperative banks. Ann Public Cooperative Econ 90(1):103-139

Barra C, Ruggiero N (2020) The role of nonlinearity on the financial development-economic performance nexus: an econometric application to Italian banks. Empir Econ. https://doi.org/10.1007/ s00181-020-01836-0

Bauducco S, Bulir A, Cihak M (2011) Monetary policy rules with financial instability. Czech J Econ Finance 61(6):545-565

Beck T, Demirguco-Kunt A, Laeven L, Levine R (2008) Finance, firm size and growth. J Money Credit Bank 40(7):1379-1405

Beck T, Levine R (2004) Stock markets, banks, and growth: panel evidence. J Bank Finance 28:423-442

Beck T, Buyukkarabacak B, Rioja F, Valev N (2012) Who gets the credit? And does it matter? Household vs. Firm lending across countries. B.E. J Macroecon 12(1), Article 2

Berger AN, DeYoung R (1997) Problem loans and cost efficiency in commercial banks. J Bank Finance 32:849-870 
Blundell R, Bond S (1998) Initial conditions and moment restrictions in dynamic panel data models. J Econom 87:115-143

Bumann S, Hermes N, Lensink R (2013) Financial liberalization and economic growth: a meta-analysis. J Int Money Finance 33(C):, 255-281

Canay IA (2011) A simple approach to quantile regression for panel data. Econom J 14:368-386

Carlson MA, King T, Lewis K (2011) Distress in the financial sector and economic activity. BE J Econ Anal Policy, 11(1), (Contributions), Article 35

Cavalcante A (2018) Investment and the banking system: a Kaleckian approach for regions in Brazil. Reg Stud 52(12):1658-1671

Chiaromonte L, Croci E, Poli F (2015) Should we trust the Z-score? Evidence from European banking system. Glob Financ J 28:111-131

Coccorese P, Silipo DB (2015) Growth without finance, finance without growth. Empir Econ 49:279-304

Crocco M, Cavalcante A, Barra C (2005) The behavior of liquidity preference of banks and public and regional development: the case of Brazil. J Post Keynesian Econ 28(2):217-240

De Serres A, Kobayakawa S, Torsten S, Vartia (2006) Regulation of financial systems and economic growth. OECD Econ Stud 43

Dow SC, Rodriguez Fuentes CJ (1997) Regional finance: a survey. Reg Stud 31:903-920

Dudley W (2011) Remarks on financial stability and economic growth at the Bretton woods committee international council meeting.

Demetriades PO, Hussein KA (1996) Does financial development cause economic growth? Time-series evidence from 16 countries. J Dev Econ 51(2):387-411

Destefanis S, Barra C, Lubrano Lavadera G (2014) Financial development and local growth: evidence from highly disaggregated Italian data. Appl Financ Econ 24(24):1605-1615

European Central Bank (2012) Financial stability review. What is financial stability? Frankfurt: European Central Bank. http://www.ecb.europa.eu/pub/fsr/html/index.en.html. Accessed 27 Nov 2018

Faggian A, Gemmiti R, Jaquet T, Santini I (2018) Regional economic resilience: the experience of the Italian local labor systems. Ann Regional Sci 60:393-410

Fiordelisi F, Mare DS (2014) Competition and financial stability in European cooperative banks. J Int Money Financ 45:1-16

Fisman R, Love I (2004) Financial development and growth in the short and long run. In: NBER working paper series 10236

Fuller D, Jonas AEG (2002) Institutionalising future geographies of financial inclusion: national legitimacy versus local autonomy in the British credit union movement. Antipode 34:85-110

Guiso L, Jappelli T, Padula M, Pagano M (2005) Financial market integration and economic growth in the EU. Econ Policy 19(40):523-577

Hakkio CS, Keeton WR (2009) Financial stress: what is it, how can it be measured, and why does it matter? Econ Rev 5-50. Federal Reserve Bank of Kansas City

Hasan I, Koetter M, Wedow M (2009) Regional growth and finance in Europe: is there a quality effect of bank efficiency? J Bank Finance 33:1446-1453

Hesse H, Cihák M (2007) Cooperative banks and financial stability. International monetary fund working paper, 2

Houston J, Lin C, Lin P, Ma Y (2010) Creditor rights, information sharing, and bank risk taking. J Financ Econ $96: 485-512$

Huang, Y. (2005). Determinants of financial development. Palgrave Macmillan UK

King RG, Levine R (1993) Finance and growth: schumpeter might be right. Q J Econ 108(3):717-737

Kondo K (2017) Introduction to spatial econometric analysis: creating spatially lagged variable in Stata, Mimeo

Laeven L, Levine R (2009) Bank governance, regulation and risk taking. J Financ Econ 93:259-275

Laeven L, Majnoni G (2003) Loan loss provisioning and economic slowdowns: too much, too late? J Financ Intermediat 12:178-197

Lown C, Morgan D, Rohatgi S (2000) Listening to loan officers: the impact of commercial credit standards on lending and output. Federal Reserve Bank NY Econ Policy Rev 6(2):1-16

Millo G, Piras G (2012) Splm: Spatial Panel Data Models in R. J Stat Softw 47:1-38

Poghosyan T, Čihák M (2011) Distress in European banks: an analysis based on a new dataset. J Financial Serv Res 40:163-184

Rojas-Suarez L (2002) Rating banks in emerging markets: what credit rating agencies should learn from financial indicators. In: Levich RM, Majnoni G, Reinhart CM (eds) Ratings, rating agencies and the 
global financial system. The New York University Salomon Center Series on Financial Markets and Institutions, vol 9. Springer, Boston

Saci K, Holden K (2008) Evidence on growth and financial development using principal components. Appl Financ Econ 18(19):1549-1560

Schumpeter JA (1934) The theory of economic development. Harvard University Press, Cambridge

Schumpeter JA (1942) Capitalism, socialism and democracy. Harvard University Press, Cambridge

Soedarmono W, Machrouh F, Tarazi A (2013) Bank competition, crisis and risk taking: evidence from emerging markets in Asia. J Int Financ Mark Inst Money 23:196-221

Stiglitz JE (1985) Credit markets and the control of capital. J Money Credit Bank 17(2):133-152

Strobel F (2011) Bank insolvency risk and Z-score measures with unimodal returns. Appl Econ Lett 18:1683-1685

Uhde A, Heimeshoff U (2009) Consolidation in banking and financial stability in Europe: empirical evidence. J Bank Finance 33:1299-1311

Usai S, Vannini M (2005) Banking structure and regional economic growth: lessons from Italy. Ann Reg Sci 39:691-714

Valverde SC, Fernández FR (2004) The Finance-growth nexus: a regional perspective. Eur Urban Regional Stud 11(4):339-354

Valverde SCD, Paso RL, Fernández FR (2007) Financial innovations in banking: impact on regional growth. Reg Stud 41(3):311-326

World Economic Forum (2012) The financial development report 2012. USA Inc, New York

Williams J, Gardener EPM (2003) The efficiency of European regional banking. Reg Stud 37:321-330

Windmeijer F (2005) A finite sample correction for the variance of linear efficient two-step GMM estimators. J Econom 126:25-51

Zazzaro A (1997) Regional banking systems, credit allocation and regional economic development. Écon Appl 1:51-74

Publisher's Note Springer Nature remains neutral with regard to jurisdictional claims in published maps and institutional affiliations. 